\title{
Nudibranchs out of water: long-term temporal variations in the abundance of two Dendrodoris species under emersion
}

\author{
Ricardo Cyrne ${ }^{1}$, Inês C. Rosa ${ }^{1}$, Filipa Faleiro ${ }^{1}$, Gisela Dionísio ${ }^{1,2}$, Miguel Baptista', Ana Couto' , Marta Pola ${ }^{3}$ \\ and Rui Rosa ${ }^{1 *}$ (1)
}

\begin{abstract}
The sudden appearance and disappearance of nudibranchs in intertidal areas have puzzled researchers all over the world, giving rise to a great diversity of theories to explain it. Here we conducted a five-year survey to evaluate seasonal changes in the abundance of Dendrodoris herytra and D. grandiflora in the Sado estuary (Portugal) and to explore a possible relationship with environmental factors such as temperature, salinity, turbidity and dissolved oxygen. Moreover, we report, for the first time, the capacity of Dendrodoris nudibranchs to tolerate emersion (unhidden and completely exposed to sun exposure) during low tides. Our results showed that both species consistently started to appear emerged in March, reaching a peak abundance between April and May, and completely disappearing in July. In both species, this temporal trend was significantly associated with water temperature, turbidity, and dissolved oxygen, but not with salinity. We argue that the sudden appearance and disappearance of these nudibranchs in intertidal areas may result from a seasonal horizontal movement of adult nudibranchs from subtidal areas to mate in intertidal areas during spring, when phytoplankton production is enhanced and planktotrophic larvae may benefit from greater food availability.
\end{abstract}

Keywords: Dendrodoris, Nudibranchs, Emersion, Aggregations, Horizontal movements, Seasonal abundance

\section{Background}

Nudibranchs are delicate, coloured and soft-body gastropod molluscs. They are characterized by having a shell and mantle cavity that are either reduced or completely absent [1]. They can be found worldwide, occupying a wide range of habitats, from marine tropical waters to cold deep Artic Ocean [2]. Nudibranch constitute important components of benthic marine ecosystems and can be commonly found grazing on the substrate, in association with corals, feeding on macroalgae, or crawling over rocks or on any other substrate [3].

For a long time, the sudden appearance and disappearance of nudibranchs in intertidal areas have puzzled

\footnotetext{
*Correspondence: rrosa@fc.ul.pt

${ }^{1}$ MARE - Marine and Environmental Sciences Centre, Laboratório Marítimo da Guia, Faculdade de Ciências da Universidade de Lisboa, Av. Nossa Senhora do Cabo 939, 2750-374 Cascais, Portugal Full list of author information is available at the end of the article
}

researchers all over the world. A great diversity of theories has been proposed to explain this phenomenon (see a comprehensive review in Table 1), but much controversy still exists regarding this issue. The most accepted theory is that nudibranchs migrate from subtidal to intertidal areas to mate and spawn [4-6]. However, several other explanations have been suggested, with some authors arguing that organisms appear inshore due to the action of tides, currents or waves $[7,8]$ or due to a fortuitous establishment of veligers [9-11]. As for the sudden disappearance of nudibranchs from the coast, death after spawning $[4,5,12]$ and ecological constraints such as food limitation and predation $[10,11]$ have been proposed as possible causes.

In 2011 we observed the appearance of the nudibranchs Dendrodoris grandiflora and D. herytra completely emerged during low tides in an oyster bank located in the Sado Estuary Natural Reserve (Portugal). This is the first 

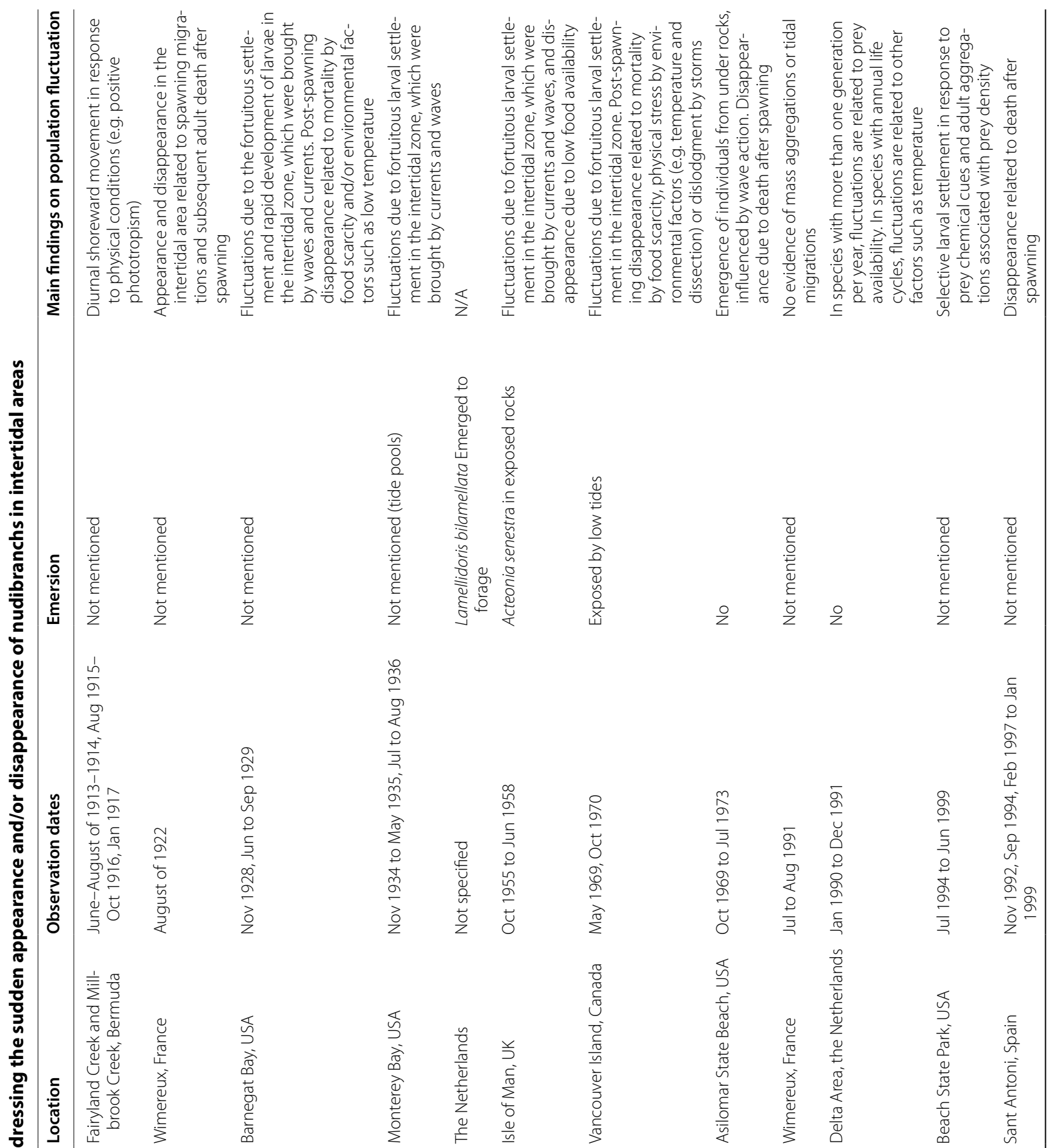

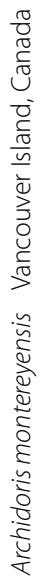
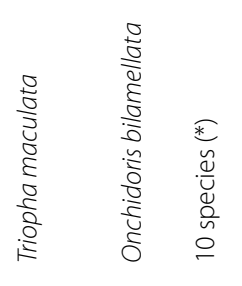

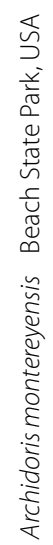
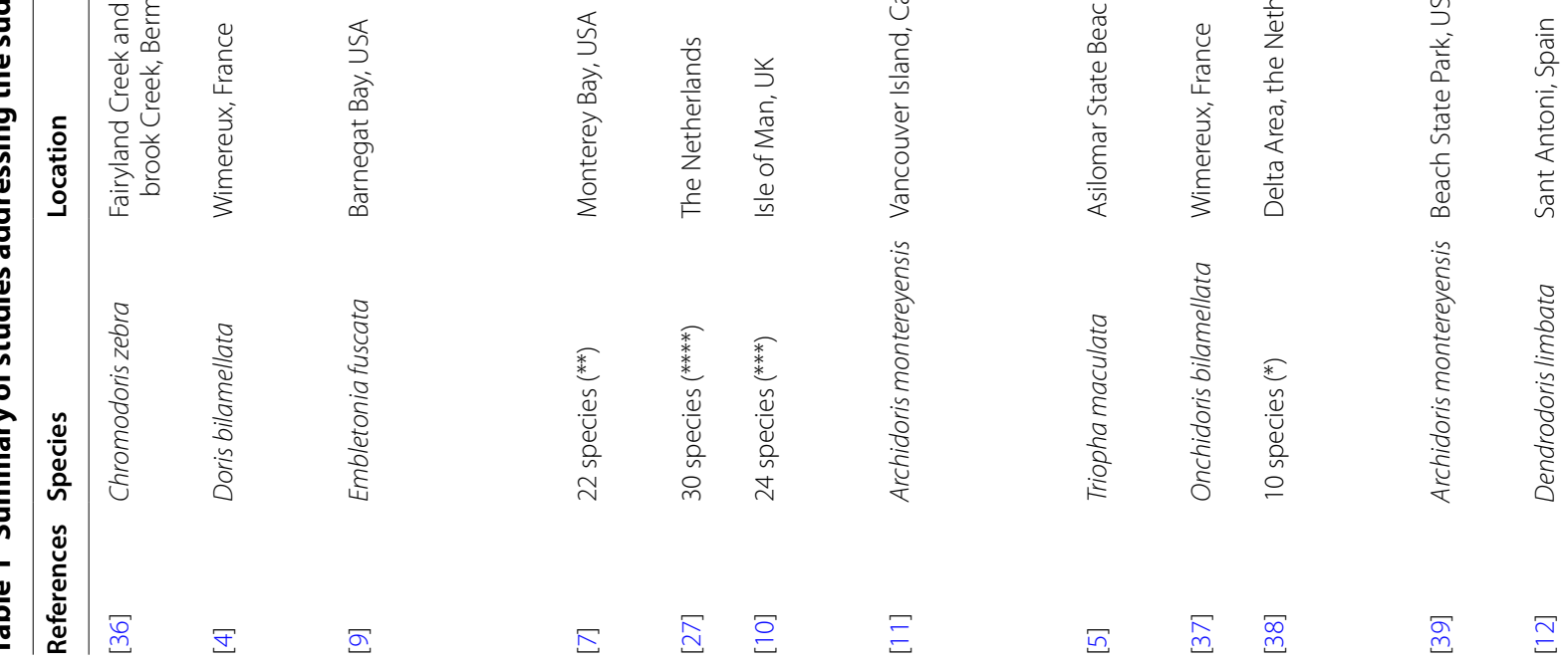

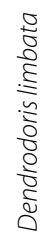

$\Xi \quad \underset{\infty}{\infty} \stackrel{\infty}{m}$

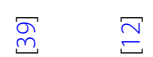




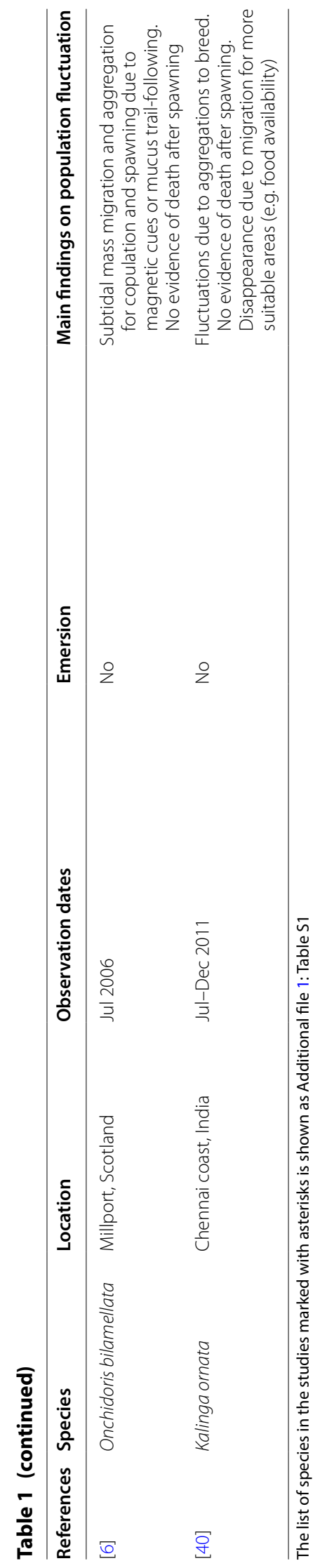


record of such a behaviour regarding these species. The genus Dendrodoris has been the subject of many studies, focusing not only on systematic descriptions [13-15], but also on chemical defences [16, 17], histology [18, 19], development [20-23], among others. Dendrodoris nudibranchs are usually found from the surface down to $25 \mathrm{~m}$ depth and are often hidden under rocks during daylight. At night, they leave their shelter to feed on sponges, their specific prey item [24].

To contribute to a better knowledge on the population dynamics and the sudden appearance and disappearance of nudibranchs in intertidal areas, the present study analyses the changes in the abundance of emerged $D$. herytra and $D$. grandiflora during a 5-year monthly survey, and investigates the possible role of environmental factors such as temperature, salinity, turbidity and dissolved oxygen to explain such temporal dynamic trends.

\section{Materials and methods \\ Study site}

This study was carried out in an oyster bank located in the Sado Estuary Natural Reserve, on the West coast of Portugal $\left(38.474857^{\circ} \mathrm{N}, 8.775255^{\circ} \mathrm{W}\right.$; Fig. 1). Given its elevation, this bank is submerged during high tides and emerged during low tides $(<0.8 \mathrm{~m}$ relative to Mean Lower Low Water), presenting a total emerged area of $1050 \mathrm{~m}^{2}$. The predominant substrate is sand and mud with a great amount of oyster and cockle shelves (Fig. 1).

\section{Nudibranch abundance}

Adult nudibranchs of the species D. herytra and D. grandiflora were visually counted monthly, between January 2011 and June 2015. Surveys were carried out during the lowest tide of the month $(<0.8 \mathrm{~m})$ and covered the entire emerged oyster bank. While looking for nudibranchs, we also looked for egg masses and sponges, the natural prey of Dendrodoris.

To evaluate if nudibranchs were sexually mature and if they die after spawning, 10 nudibranchs of each species were collected during the peak of abundance in April 2015 and transported to the aquaculture facilities of Laboratório Marítimo da Guia (Cascais, Portugal). They were kept in two separate groups aquaria, in recirculating systems under the same conditions as those observed in the study area (i.e. $\mathrm{pH} 8.0$; salinity 35 , temperature $21^{\circ} \mathrm{C}$ ). Individuals were not fed and were maintained for 15 days in those conditions. The occurrence of mating, spawning and death after spawning was assessed. Organisms considered dead where normally found at the bottom upside down. Death was confirmed after loss of mobility, increase of mucus release, high loss of colour, and loss of muscular flexibility.

\section{Environmental conditions}

To establish a connection with the abundance of nudibranchs, environmental data were collected between January 2011 and June 2015. Water temperature, turbidity and dissolved oxygen were measured with a multiparameter probe (CTD YSI 6600 V2, Tropical Marine Centre, Portugal) and salinity was measured with a refractometer ( $\mathrm{V}^{2}$ Refractometer, Tropical Marine Centre, Portugal) with a precision of \pm 1 . Measurements were made in the surroundings of the emerged bank during low tide when nudibranchs were observed and collected.

\section{Statistical analyses}

To investigate the relation between $D$. herytra and $D$. grandiflora abundance and environmental variables, a generalized additive model (GAM) with a zero-inflated Poisson (ZIP) family was used for each species. The ZIP model is especially useful to analyse count data with many zero observations, such as our data [25]. Prior to statistical analyses, the independency of environmental variables was checked using a correlation matrix.

The method used to choose the best model was an "all possible subsets" method of analysis, in which several models were created for all possible combinations of variables. Akaike Information Criterion (AIC) was used to select the most parsimonious model. Based on these results, the final model included water temperature, salinity, turbidity and dissolved oxygen as independent variables. A mix of smooth and parametric model components was used [26]. For D. grandiflora, a thin plate regression spline with "shrinkage" was fitted [26] to water temperature, turbidity and dissolved oxygen, while for $D$. herytra the same smooth parameter was fitted only to turbidity and dissolved oxygen.

All statistical analyses were implemented in R (version 3.1.1), using the mgcv package [26].

\section{Results}

\section{Nudibranch abundance}

Nudibranchs were mostly encountered emerged, but some were occasionally found in small tidal pools or under oyster shelves. Most of the individuals were found alone, static, and some upside down. No dead animals, egg masses or sponges (their natural prey) were encountered in any of the monthly surveys during the 5 years. The highest abundance of both species was observed during the first year of observations (i.e. 2011), followed by the year 2013 (Fig. 2). An accentuated decrease in nudibranch abundance was observed in 2012 and 2015. In general, D. grandiflora presented higher abundances than $D$. herytra (Fig. 2). 


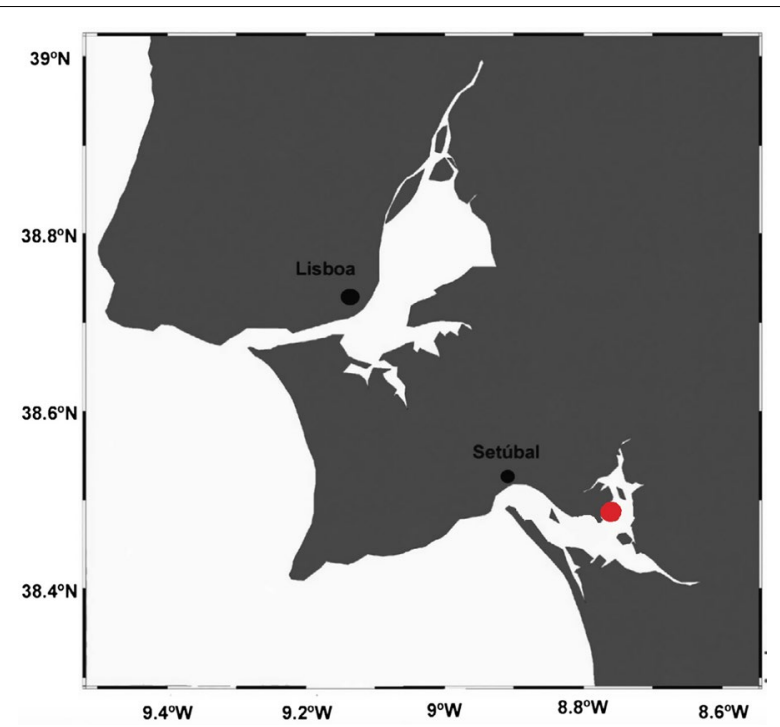

Fig. 1 Map of the study area, an oyster sandbank located in the Sado Estuary National Reserve, West coast of Portugal $\left(38.474857^{\circ} \mathrm{N}\right.$, $\left.-8.775255^{\circ} \mathrm{W}\right)$

The appearance of emerged nudibranchs presented a marked seasonal pattern (Fig. 2). Nudibranchs were observed from March to June, mainly during April and May, and disappeared completely from July onwards. This pattern was consistent during the five consecutive years, with just a few small changes observed over time. For instance, in 2011 nudibranchs of both species started to appear emerged in April (Fig. 2), while in the following years (i.e. from 2012 to 2015) they started to appear earlier in March (Fig. 2), although in very low numbers. The maximum abundance was always reached in April (Fig. 2), except for 2014 when the peak was reached later in May (Fig. 2). Afterwards, nudibranchs' abundance started to decrease until a complete disappearance in July (Fig. 2), although in 2014 they disappeared abruptly in June (Fig. 2).

Nudibranchs captured in April 2015 and kept under laboratory conditions were seen copulating and spawning as soon as they arrived at the lab (Fig. 1), which indicates that the organisms from the study population were sexually mature during the peak of abundance of that year. Moreover, we found no evidence of death after spawning, with some individuals spawning more than once.

\section{Environmental conditions}

Variation in the environmental parameters of the Sado estuary, from January 2011 to June 2015, is presented in Fig. 3. Water temperature, as well as turbidity, showed consistent patterns throughout the five years of observations.
As expected, water temperature showed an increasing trend from winter to summer months, almost like a bellshaped graph (Fig. 3A1-A6). Maximum water temperatures occurred between June and August, depending on the year. Salinity showed no clear pattern (Fig. 3B1-B6). Turbidity varied generally between 1 and 5 NTU during most of the year, except for March and April, when it could reach values as high as $75 \mathrm{NTU}$ (Fig. 3C1-C6). Dissolved oxygen varied between $60 \%\left(4.5 \mathrm{mg} \mathrm{l}^{-1} \mathrm{O}_{2}\right.$ around $\left.26^{\circ} \mathrm{C}\right)$ and $150 \%$ (12.7 $\mathrm{mg} \mathrm{l}^{-1} \mathrm{O}_{2}$ around $13^{\circ} \mathrm{C}$ ), with a sharp increase occurring in the beginning of the spring season and reaching a peak in April or May depending on the year (Fig. 3).

\section{Relationship between nudibranch abundance and environmental conditions}

The explanatory ability of the models was good, with an explained deviance of $85.5 \%$ for D. herytra and $98.1 \%$ for $D$. grandiflora. For both species, water temperature, turbidity and dissolved oxygen showed significant effects on nudibranchs' abundance $(p<0.05)$, but not salinity $(p>0.05$; Table 2). Higher abundances occurred at temperatures generally between $17{ }^{\circ} \mathrm{C}$ and $21^{\circ} \mathrm{C}$ (except for 2014, when it reached $24^{\circ} \mathrm{C}$ ), but only in spring and not during autumn months. On the other hand, higher abundances were preceded by the peak in turbidity, coincided with the peak in dissolved oxygen (Fig. 3).

\section{Discussion}

\section{Emersion and microhabitat selection}

Nudibranchs are known for their sudden appearance and disappearance in intertidal areas (see Table 1), but reports of emerged nudibranchs are scarce [10,11,27]. The present work constitutes the first comprehensive report of the seasonal occurrence of emerged nudibranchs during low tides. In contrast to other molluscs, nudibranchs do not possess a shell that protects them from desiccation and allows them to create a high humidity environment within their shells. Instead, they usually seek areas of great humidity and refuge beneath rocks or other shelters (see more about microhabitat selection in [28]). Although nudibranchs are generally not found in unsheltered and open areas, in the present study we showed that dozens of individuals were emerged at low tides during spring months. Nevertheless, it is worth mentioning that the texture of the substratum (i.e. oyster shell bank) seems to play an important role in microhabitat selection by Dendrodoris species, since all the other intertidal banks in the surrounding area-without oyster shells coverage and mostly constituted by mud substrate with little sand-never revealed any emerged specimens. From this, we argue that oyster shells must provide some crypsis by providing a disrupted visual background that might contribute to a reduction in visual predation. Also, this could mean that oyster shells protect nudibranchs 
(See figure on next page.)

Fig. 2 Monthly variations in the abundance of emerged Dendrodoris grandiflora (dark bars) and D. herytra (yellow bars) during low tide at the oyster sandbank (1050 $\mathrm{m}^{2}$ ), from January 2011 to June 2015

from dehydration. However, the fact that most nudibranchs were not beneath the shells makes this microhabitat selection argument incomplete.

\section{Horizontal migrations and spawning}

There is a great diversity of theories that explain the sudden appearance and disappearance of nudibranchs in intertidal areas (as synthesized in Table 1). However, it is still unknown if these events are related with horizontal migrations, and what are the causes that motivate these movements. Some authors state that, as a result of these horizontal migrations, nudibranchs seasonally appear as mass aggregations in intertidal areas to mate and spawn $[4,6]$. In our surveys, organisms were mostly seen isolated and no egg masses were seen in the study site. This way, it seems unlikely that the nudibranchs were in the study area to mate or to spawn. Nonetheless, the individuals that were brought to the laboratory immediately started to copulate and spawned, indicating that they were sexually mature. Thus, the hypothesis of a horizontal migration to intertidal areas to mate should not be set aside and further studies are necessary to clear this out.

The sudden disappearance of nudibranchs from intertidal areas has often been attributed to death after spawning $[4,6]$. During our surveys, we did not observe dead individuals in the field or any evidence of death after spawning in the specimens kept in the laboratory, with some nudibranchs spawning more than once. This way, our results with Dendrodoris spp. do not support this hypothesis. However, and like other molluscs, death after spawning may be a species-specific trait. While a similar pattern was observed for Onchidoris bilamellata, a species that spawns several times before dying [29], other nudibranchs seem to experience death after spawning (e.g. Archidoris montereyensis, in [11]).

\section{Environmental determinants}

The abundance of $D$. herytra and D. grandiflora was correlated with most of the assessed environmental factors, namely water temperature, turbidity and dissolved oxygen. Our long-term survey consistently showed that both species appeared emerged during the low tides of the spring months. They started to appear in March and their abundance was highest between April and May, when water temperatures were generally between 17 and $21^{\circ} \mathrm{C}$ (except for 2014 , when it reached $24{ }^{\circ} \mathrm{C}$ ). Both species completely disappear in July, before the high summer temperatures. A study conducted in the western Atlantic revealed that most nudibranchs have high thermal sensitivity and that some species disappear with rising summer temperatures [30]. A negative impact of high temperatures on $D$. herytra and $D$. grandiflora may in part explain their disappearance from the intertidal area at the end of the spring. Nevertheless, temperature alone cannot explain their presence only during spring, since no nudibranchs were observed at similar temperatures in autumn.

The presence of D. herytra and D. grandiflora in the intertidal area was consistently related with a peak in turbidity and dissolved oxygen. Elevated turbidity and oxygen super saturation (values exceeding 100\%) can be related with spring blooms that result from an increase in phytoplankton biomass and photosynthesis during spring [31-33]. As a result, secondary productivity also increases, including zooplankton grazers [34], which benefits $D$. grandiflora's planktotrophic larvae [22]. In addition, high turbidity and dissolved oxygen may be a result of turbulence which in turn will help the distribution of planktonic larvae in the water column [35]. This way, Dendrodoris planktonic life stages may benefit from increasing phytoplankton concentration. However, it is noteworthy that no sponges (the prey of the adults of Dendrodoris spp. [24]) were found in the study location during the 5 years of survey. It is also important to notice that elevated turbidity consistently preceded an increase in nudibranchs abundance (also accompanied by the peak of dissolved oxygen). Thus, we hypothesize that the increase in turbidity is the key environmental factor that triggers the migration of nudibranchs.

In conclusion, the present work constitutes an additional example of a nudibranch population that seasonally appears in intertidal areas, but the first comprehensive report of nudibranchs under tidal emersion. The sudden appearance and disappearance of Dendrodoris nudibranchs in intertidal areas may result from a seasonal horizontal movement of adult nudibranchs from subtidal areas to mate in intertidal areas during spring, when phytoplankton production is enhanced and planktotrophic larvae may benefit from greater food availability. However, further studies are required to test this hypothesis. 


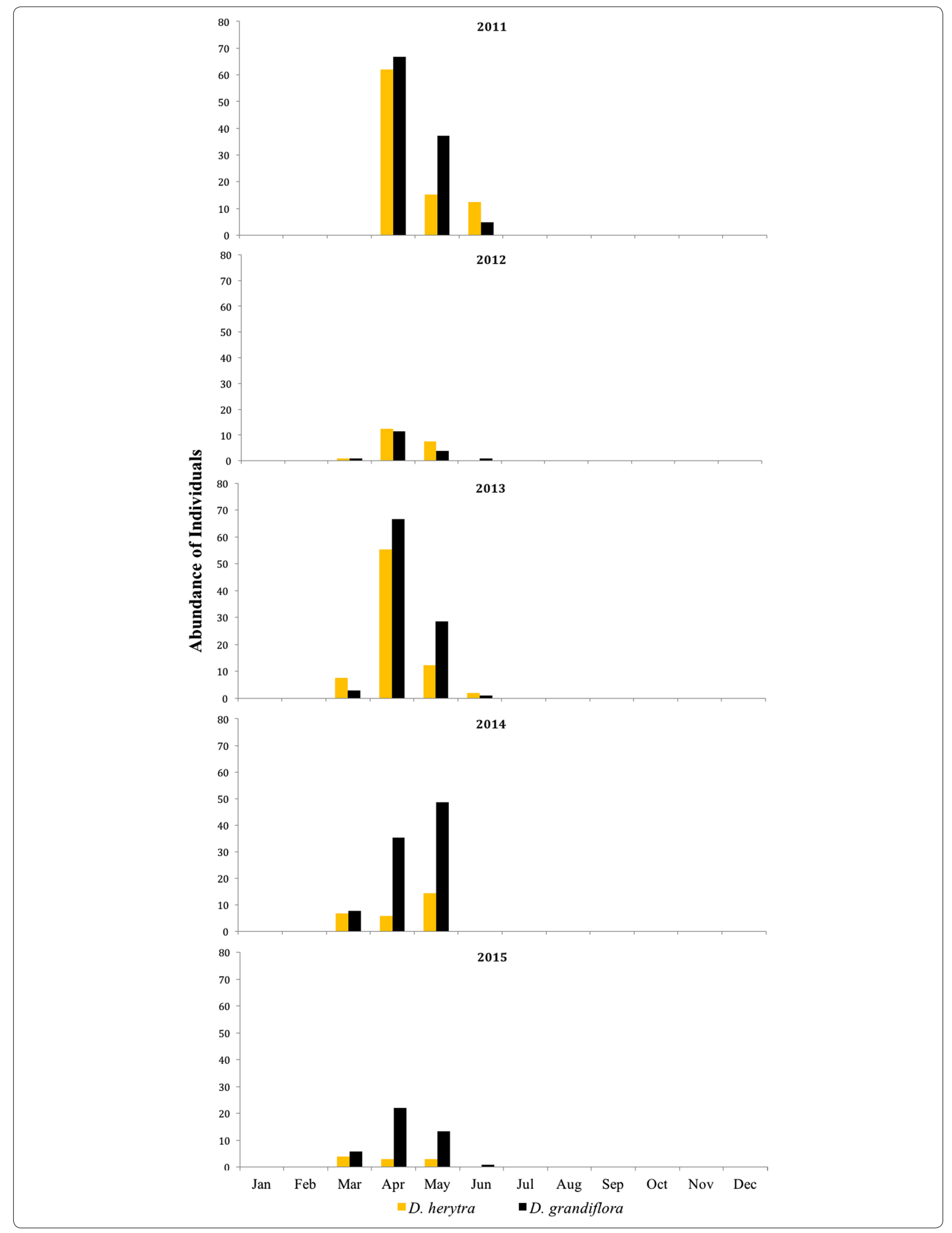




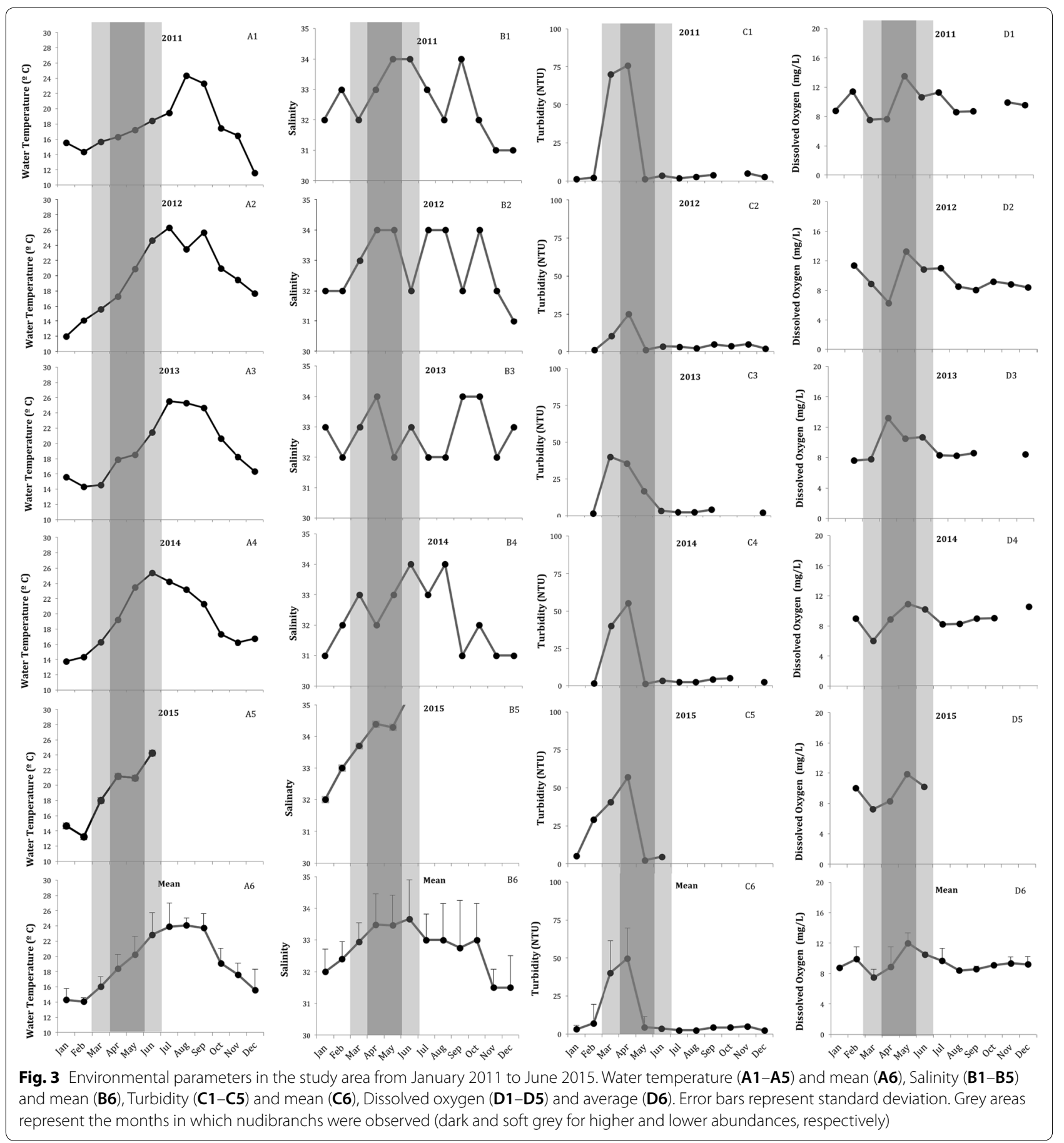

\section{Additional file}

Additional file 1: Table S1. List of the species analyzed in the four multispecies study synthesized in Table 1.

\section{Authors' contributions}

$R C, I R, F F, G D, M P$ and $M B$ contributed with field work and paper review; AC contributed with Statistical Analysis; RR contributed with paper review, field work and experimental design. All authors read and approved the final manuscript.

\section{Author details}

1 MARE - Marine and Environmental Sciences Centre, Laboratório Marítimo da Guia, Faculdade de Ciências da Universidade de Lisboa, Av. Nossa Senhora do Cabo 939, 2750-374 Cascais, Portugal. ${ }^{2}$ Departamento de Biologia and CESAM, Universidade de Aveiro, Campus de Santiago, 3810-193 Aveiro, Portugal. ${ }^{3}$ Departamento de Biología, Edificio de Biología, Campus de 
Table 2 Results of Generalized additive models (GAMs)

\begin{tabular}{|c|c|c|c|}
\hline & $\beta$ & sd & $p$ \\
\hline \multicolumn{4}{|l|}{ Dendrodoris herytra } \\
\hline \multicolumn{4}{|l|}{ Parametric coefficients } \\
\hline Water temperature & -0.0985 & 0.04 & $0.0096^{*}$ \\
\hline Salinity & 0.3413 & 0.15 & 0.2773 \\
\hline \multicolumn{4}{|l|}{ Smooth terms } \\
\hline s (Turbidity) & & & $<2.00 \mathrm{e}-16^{*}$ \\
\hline s (Dissolved oxygen) & & & $1.05 e-15^{*}$ \\
\hline \multicolumn{4}{|l|}{ Dendrodoris grandiflora } \\
\hline \multicolumn{4}{|l|}{ Parametric coefficients } \\
\hline Salinity & 0.4638 & 0.25 & 0.0606 \\
\hline \multicolumn{4}{|l|}{ Smooth terms } \\
\hline s (Water temperature) & & $7.15 \mathrm{e}-07^{*}$ & \\
\hline s (Turbidity) & & & $<2.00 \mathrm{e}-16^{*}$ \\
\hline s (Dissolved oxygen) & & $1.09 e-14^{*}$ & \\
\hline
\end{tabular}

Approximate significance levels $(p)$ are displayed for each covariate $(*$ represents a significance level of 0.05 ). Slope $(\beta)$ and standard deviation (sd) are shown for parametric coefficients

Excelencia Internacional UAM+CSIC, Universidad Autónoma de Madrid, C/ Darwin 2, 28049 Madrid, Spain.

\section{Acknowledgements}

The authors would like to thank Vanessa Pires, Vanessa Lopes, Marta Pimentel and Luis Narciso for their help in the field work. The authors also acknowledge the suggestions of the anonymous reviewers that greatly improved this manuscript.

\section{Competing interests}

None of the authors have any kind of competing interests with any other author or Institution regarding the data presented in this work. Authors disclose all relationships or interests that could have direct or potential influence or impart bias on the work.

\section{Consent for publication}

Not applicable.

\section{Ethics approva}

All the authors followed the Ethical Responsibilities according to the Committee on Publication Ethics (COPE).

\section{Funding}

The Portuguese Foundation for Science and Technology (FCT) supported this study through the strategic project granted to MARE UID/Multi/04378/2013, FCT Investigator Consolidation Grant to R. Rosa, doctoral grants to G.D. (SFRH/ BD/73205/2010) and M.B. (SFRH/BD/88175/2012) and a post-doc grant (SFRH/ BPD/79038/2011) to F.F.

\section{Publisher's Note}

Springer Nature remains neutral with regard to jurisdictional claims in published maps and institutional affiliations.

Received: 3 February 2018 Accepted: 23 August 2018

Published online: 27 August 2018

\section{References}

1. Wägele H, Klussmann-Kolb A, Verbeek E, Schrodl M. Flashback and foreshadowing-a review of the taxon Opisthobranchia. Org Divers Evol. 2014;14(1):133-49.

2. Dionisio G, Rosa R, Leal MC, Cruz S, Brandao C, Calado G, Serodio J, Calado R. Beauties and beasts: a portrait of sea slugs aquaculture. Aquaculture. 2013;408:1-14.

3. Behrens DW, Valdés A. A new species of Dendrodoris (Mollusca: Nudibranchia: Dendrodorididae) from the Pacific coast of North America. Proc Calif Acad Sci. 2004;55:408-13.

4. Pelseneer P. Sur une habitude de Doris bilamellata. Ann Soc R Zool Belg. 1922;53:28-32.

5. Nybakken J. Abundance, diversity and temporal variability in a California intertidal nudibranch assemblage. Mar Biol. 1978;45:129-46.

6. Claverie T, Kamenos NA. Spawning aggregations and mass movements in subtidal Onchidoris bilamellata (Mollusca: Opisthobranchia). J Mar Biol Assoc UK. 2008;88(1):157-9.

7. Costello DP. Notes on the breeding habits of the nudibranchs of Monterey Bay and vicinity. J Morphol. 1938;63(2):319-43.

8. Willows AOD. Shoreward orientation involving geomagnetic cues in the nudibranch mollusc Tritonia diomedea. Mar Freshw Behav Phys. 1999;32(2-3):181-92.

9. Chambers LA. Studies on the organs of reproduction in the nudibranchiate mollusks. Bull Am Mus Nat Hist. 1934;66:599-641.

10. Miller MC. Annual cycles of some Manx nudibranchs, with a discussion of the problem of migration. J Anim Ecol. 1962;31(3):545-69.

11. Crane SV. Population ecology of the nudibranch Archidoris montereyensis. Simon Fraser University; 1972

12. Domenech A, Avila C, Ballesteros M. Spatial and temporal variability of the opisthobranch molluscs of Port Lligat Bay, Catalonia, NE Spain. J Molluscan Stud. 2002;68:29-37.

13. Valdes A, Ortea J, Avila C, Ballesteros M. Review of the genus Dendrodoris Ehrenberg, 1831 (Gastropoda: Nudibranchia) in the Atlantic Ocean. J Molluscan Stud. 1996;62:1-31.

14. Brodie GD, Willan RC, Collins JD. Taxonomy and occurrence of Dendrodoris nigra and Dendrodoris fumata (Nudibranchia: Dendrodorididae) in the Indo-West Pacific region. J Molluscan Stud. 1997;63:407-23.

15. Hirose M, Hirose E, Kiyomoto M. Identification of five species of Dendrodoris (Mollusca: Nudibranchia) from Japan, using DNA barcode and larval characters. Mar Biodivers. 2015:45(4):769-80.

16. Fontana A, Ciavatta ML, Miyamoto T, Spinella A, Cimino G. Biosynthesis of drimane terpenoids in dorid molluscs: pivotal role of 7-deacetoxyolepupuane in two species of Dendrodoris nudibranchs. Tetrahedron. 1999;55(18):5937-46.

17. Fontana A, Villani G. G. C. Terpene biosynthesis in marine molluscs: incorporation of glucose in drimane esters of Dendrodoris nudibranchs via classical mevalonate pathway. Tetrahedron Lett. 2000;41:2429-33.

18. Wägele H, Brodie GD, Klussmann-Kolb A. Histological investigations on Dendrodoris nigra (Stimpson, 1855) (Gastropoda, Nudibranchia, Dendrodorididae). Molluscan Res. 1999;20:79-94.

19. Brodie GD. Some comparative histological aspects of the dendrodorid genera Doriopsilla and Dendrodoris (Opisthobranchia: Nudibranchia). Boll Malacol. 2001;37:99-104.

20. Gohar HAF, Soliman GN. The biology and development of Dendrodoris (=Doridopsis) fumata (Rüppell and Leuckart) (Gastropoda, Nudibranchia). Pub Mar Biol Stat, Al-Ghardaqa, Red Sea. 1967;14:31-54.

21. Shyamasundari $K$, Najbuddin M. Experimental investigations of salinity and temperature effects on early developmental stages in Dendrodoris (Doriopsilla) miniata (Alder \& Hancock) (Gastropoda Opisthobranchia). Monit Zool Ital. 1976;10:93-104.

22. Goddard JH. Ametamorphic direct development in Dendrodoris behrensi (Nudibranchia: Dendrodorididae), with a review of developmental mode in the family. Proc Cal Acad Sci. 2005;59:201-11.

23. Brodie GD, Calado G. Dendrodoris arborescens (Collingwood, 1881) (Mollusca: Nudibranchia): larval characteristics reveal a masked porostome species. Rec West Aust Mus. 2006;69:119-26.

24. Calado G, Silva JP. Lesmas do Algarve-Guia de Moluscos Opistobrânquios da Costa Sul do Algarve. Portimão: Subnauta; 2012.

25. Arab A, Wildhaber ML, Wikle CK, Gentry CN. Zero-inflated modeling of fish catch per unit area resulting from multiple gears: application to 
channel catfish and shovelnose sturgeon in the Missouri River. N Am J Fish Manag. 2008;28(4):1044-58.

26. Wood SN. Generalized additive models: an introduction with R. Boca Raton, FL: Chapman Hall/CRC; 2006.

27. Swennen C. Data on distribution, reproduction and ecology of the nudibranchiate molluscs occurring in the Netherlands. Neth J Sea Res. 1961:1:191-240

28. Barbeau MA, Durelle K, Aiken RB. A design for multifactorial choice experiments: an example using microhabitat selection by sea slugs Onchidoris bilamellata (L.). J Exp Mar Biol Ecol. 2004;307(1):1-16.

29. Todd CD. Settlement-timing hypothesis: reply to Grant and Williamson. Mar Ecol Prog Ser. 1985;23:197-202.

30. Clark KB. Nudibranch life cycles in the Northwest Atlantic and their relationship to the ecology of fouling communities. Helgol Wiss Meeresunters. 1975;27:28-69.

31. Barlow RG, Mantoura RFC, Gough MA, Fileman TW. Pigment Signatures of the Phytoplankton Composition in the Northeastern Atlantic during the 1990 Spring Bloom. Deep-Sea Res Pt II. 1993:40(1-2):459-77.

32. Butler W, Coste JH. Seasonal variations in the dissolved oxygen content of the water of the Thames estuary. With special reference to the phenomenon of supersaturation. Biochem J. 1923;17(1):49-58.
33. O'Boyle S, McDermott G, Wilkes R. Dissolved oxygen levels in estuarine and coastal waters around Ireland. Mar Pollut Bull. 2009;58(11):1657-63.

34. George JA, Lonsdale DJ, Merlo LR, Gobler CJ. The interactive roles of temperature, nutrients, and zooplankton grazing in controlling the winter-spring phytoplankton bloom in a temperate, coastal ecosystem, Long Island Sound. Limnol Oceanogr. 2015;60(1):110-26.

35. Scheltema R. On dispersal and planktonic larvae of benthic invertebrates: an ecletic overview and summary of problems. Bull Mar Sci. 1986:39:290-322

36. Crozier WJ. On the periodic shoreward migrations of tropical nudibranchs. Am Nat. 1917:51:377-82.

37. Thompson TE. Migrations of Onchidoris-Bilamellata during Tidal Emersion — a refutation. J Molluscan Stud. 1984;50:123.

38. Aerts LAM. Seasonal distribution of nudibranchs in the southern Delta area, SW Netherlands. J Molluscan Stud. 1994;60:129-39.

39. Knowlton AL, Highsmith RC. Convergence in the time-space continuum: a predator-prey interaction. Mar Ecol Prog Ser. 2000;197:285-91.

40. Shrinivaasu S, Venkatraman C, Rajan R, Padmanaban P, Venkataraman K. Abundance and spawning of Kalinga ornata (Mollusca: Gastropoda: Opisthobranchia). CIBTech J Zool. 2013;56:2319-3883.
Ready to submit your research? Choose BMC and benefit from:

- fast, convenient online submission

- thorough peer review by experienced researchers in your field

- rapid publication on acceptance

- support for research data, including large and complex data types

- gold Open Access which fosters wider collaboration and increased citations

- maximum visibility for your research: over $100 \mathrm{M}$ website views per year

At BMC, research is always in progress.

Learn more biomedcentral.com/submissions 